\title{
The Nature of Nation Character Establishment through Educational Local Uniqueness Basis (ELUB)
}

\author{
Warman, Suryaningsih ${ }^{1}$, Demsy Salimdeho ${ }^{2}$ \\ ${ }^{1,2}$ Dept. of Civic Education, Faculty of Teacher Training and Education, Mulawarman University, Indonesia \\ warman@fkip.unmul.ac.id
}

\begin{abstract}
This writing is about: (1) concept and the law of education ELUB, (2) the introduction environmental identity through learning environment, and (3) the meaning of wise words that contain motivation in local language. The idea of education based the local uniqueness started from an expression delivered which responded and developed by some social experts that became expression "thinks globally acts locally". National education can be used to develop skill, character building as well as national civilization to create a good nation. The aim of national education is to develop student's potential in order to become wise, faith, have faith in god, good, healthy, creative, independent, democratic and responsible. The benefits of education based on local wisdom: (a) create a generation who competent and dignified; (b) reflecting the cultural values; (c) participated in develop character of the nation, (d) contribute to create the identity of the nation, and (e) participated by conserve the culture of the nation. The methodology that used for the introduction of the identity of the environment learning in the local wisdom vary greatly, like: (a assigning the students to make an article about potential places, (b) teach them how to draw an limasan and joglo (Javanese traditional house), (c) introduce geometrical shapes of traditional house in Indonesia, (d) story telling about traditional house in Indonesia with picture, sound and the miniature of traditional house itself. Moral value that contain of motivation in local language: (a) rame ing gawe sepi ing pamrih; (b) ing ngarsa sung tulada, ing madya mangun karsa, tutwuri handayani; (c) becik ketitik olo ketoro. Education based on local wisdom has a big potential in creating Indonesian's people with Character. A phrase said that" great nation is a nation that does not leave their history". Big is just not enough, but also have to go forward. To became the big nation so the country should valuable and have their own character.
\end{abstract}

Keywords: nation character; education; local wisdom

\section{INTRODUCTION}

The existence of a nation is very much determined by characters of the nation itself[1]. The stronger character of the nation, the nation are able to make them as a dignity and make the other consider how stronger they are. So, Indonesia should maintain this character.

There is a tendency that Indonesian's character changes into destructive way, for examples, religious, well mannered, calm, respect to each other, and give a priority to talk to each other first before doing something. The people of Indonesia has changes very radical in all the center of life .Both in political dimensions, social, culture, economic, and so on [2].

The sustainability of national and state as if as disconnected with the history of the nation itself, which ideology values and cultural values get less proper attention, the unity started to fade, and spiritual development also material yet reached the goal that we want [3].

These condition affected by globalization factor, which allows borderless information. In these situation there was a process of trans-cultural and cross cultural which unite cultural values one into another. Cultural contact can produce two possibilities, (1) assimilation, the meeting without any new meaningful values; and (2) acculturation, meeting with new meaningful values [11].

Education is the dominant factor in developing character of a nation. Education as transforming culture process are cultural legacy from one to another [4]. Education is the process to create human to have humanity, mature, and became completely human to be able to run and develop culture [5]. Culture are the whole result of human that lived in the society as a member of the society itself whose smart, trusted, artistic law and customs.

In the globalization era, has made an institution of education lost the motion, and the implication because of student's less of historical knowledge. Because of that, we have to be able to protect our cultural variety.

Education based on local knowledge in accordance as government efforts to conserve the cultural in Indonesia. Such as education who use excellence localized in the economic aspect, culture, language, information technology and communication, ecology, and others, all of which beneficial for the development of the students [6]. Education based the local uniqueness beneficial, such as: (a) create a generation who competent and dignified; (b) reflecting the cultural values; (c) participated in develop character of the nation, (d) contribute to create the identity of the nation, and (e) participated by conserve the culture of the nation.

This writing will discuss conceptually (1) How regulation arrange the educational local uniqueness basis (ELUB)?; (2) how introduction method of identity through the learning, and (3) how the meaning of wisdom words that contain motivation in local language (Javanese) ? 


\section{LITERATURE REVIEW}

Education based local knowledge is the education that the more based on enrichment cultural values [6], [7]. It teaches education school tuition to is always close to the situation concrete they face daily .In other words educational model it calls to all of us to always be near and keep the state of around which is value in the local communities .Educational model this be identified with some things as follows:

\section{A. The Concept and dan the law of (ELUB)}

The idea of education based on local knowledge began with a phrase delivered by [1] and responded and developed by some experts social said "thinks globally acts locally" [8]. The meaning of that phrase was, someone could take any experience and the knowledge, of any ethnic group and any nation, and however in the action when someone be in a new place, then he should be based on cultural values that happen in those places.

With the knowledge which is global, someone can be easily read and identify a problem and solved it. Then someone needs to know much in order to make them have so much knowledge [9]. But in the general knowledge of education especially in teaching, a teacher it is not enough to with so much knowledge and open-minded, but to reflect "transfer of knowledge" it also accompanied by emotion skill which are how an educator should be able to entered the world in which students are located [10]. In this case there is one thing that should we remember is "a student that came to school it is not like an empty glass, but they have already brought their own knowledge from their home". In other words it stated that students have different environment one to another. So their social and economy must be different. So that in the community, we must have different from one to another but we have to remember that we are "one" Indonesia. Just like our "Bhineka Tunggal Ika" that meant we have different cultures and ethnic group but we one Indonesia.

Education based on local knowledge is reflection of realization from the government regulation number 19 year 2005 about standard National education, in section 17 paragraph 1 that explain "curriculum in Senior High school and elementary school, or the other of equal rank would be develop based on the educational rank, the potential of area itself, social culture and the students itself'.

In law no 20 years 2003 about the national education system in paragraph 3 , states that national education serves develop the ability and form the character of the people and civilization a dignified in order to brightness people's life. National education aims to the potential of the nation to believe and fear one God, well mannered, healthy, knowledge, capable, creative, independent, and into a citizen democratic and responsible.

While the benefit of education based local knowledge such as (a) Create a generation who competent and dignified; (b) Reflecting the cultural values; (c) Participated in develop character of the nation; (d) Contribute to create the identity of the nation; (e) Participated by conserve the culture of the nation.
Talking about value, then we can't separate it with integrity, which meant identity of the nation itself. A research in Harvard University (Ali Ibrahim Akbar, 2000) in (Leo Agung, 2011), stated that how successful someone can't be indicated by the knowledge and the hard skill, but it more like how is someone can take care of himself and other (soft skill). This research stated that success is about $20 \%$ of hard skill and the rest is $80 \%$ soft skill [11].

The statement above can be simplified with value expression. The meaning of value is an integrity that will be an identity in a Nation. With that value, a Nation will be developed and prestigious. It also happened in educational world. A teacher, could not separate from simplify word which is a value. Because of a value, a teacher will have integrity that makes an identity in the end, and with identity a teacher will he have his/her iconic which make the differences with other teachers. Here usually be found inclination that happened in teachers society which is they often race each other with previous teaching method and has learned before. They didn't realize that integrity could not be simplified with a method only. As good as method, if without the integrity in his/her self then the method will not be effective. The way that teacher can do, a teacher or students, is increase their potential value in the local society. Based on that experience, a teacher or students will get change in educational world that has been processed.

This is based on a statement from an intellectual from Morocco, Almarhum Muhammad Abed Al-Jabiri said "Attajdidu mina dhdhahl" changes must come from our tradition, and it doesn't mean changes with take from other people or other countries.

\section{B. Introduction of environment identity through learning media}

A method that can be used to introducing an environment in learning local beauty actually so variation [6]. For SMP-SMA students, Indonesian language teachers, English and Javanese language teachers, can give assignments to students to make an essay about tourism city potential. For art teachers, can give the lesson about how to draw serotongan house, limasan and joglo. For Math teachers, can introduce geometries shaped to students through shape of traditional house. Another method can be practiced is through story telling activity, with pictures, doll, instrument, traditional house miniature, or teacher's stuff. This method more effective to give educational value in pre-school, kindergarten, and elementary school.

\section{Wise words with motivational value in local language (Java)}

In a locality usually has so many iconic culture and has high value. Which are good quotes/wise words that always become a uniqueness in daily activity (Java), for the example:

\section{1) Rame ing Gawe Sepi ing Pamrih:}

Sentences have a command or invitation, that is asking for someone will be kind to people, no matter who is he/she, and not expect for any reward from what have done.

From the quotes can be imagine, what will happen if almost off the society can get the point and apply the quotes in their 
daily activity? Next question is what will happen, if all of the leaders and government can get the point and apply in their activity? From the quotes, we can see that actually value from a local culture is amazing.

\section{2) Ing Ngarsa Sung Tulada, ing Madya Mangun Karsa,} Tutwuri Handayani:

The sentence is an asking for someone to adapt to his/her self in good position. If he/she become a leader then he/she be able to instructor, if have position in a chief of government, then he/she should be able to keep he/she work quality, and if he/she becomes a member of government then he should be able to give educational value (support and give the strength)

\section{3) Becik Ketitik Olo Ketoro:}

This sentence gives inspiration to anyone that someone should do what he/she has done. With that way, then there's no excuse to someone to do something bad, because it absolutely that kind of person could not get the happiness in the end.

From three expressions of wise words above, enough to be an example that how glorious is value potential in Indonesian tradition. From those examples above it were just a few examples that took from one local society in Indonesia that is Java, even there's so many ethnics in Indonesia, that each ethnic has its uniqueness. Like Bataknese with their open minded, java with smooth accent, and Madura with their pride. Then now about the question is how each values that has been a uniqueness in each local tradition will be safe and deserve good treats, also apply in each life aspect [12]. After that it mixed to create one Nation that is Indonesia, and it should be amazing right?

With those phenomena that happened in Indonesia recently, absolutely all of us as Indonesian people feel sad. It also happening in educational world, this time we should be front guard in create Indonesia be better character mission and started from applying education with beauty local basic.

\section{RESULT AND DISCUSSION}

The idea of education based on local knowledge began with a phrase delivered by [1] in and responded and developed by some experts social said "thinks globally acts locally ".the meaning of that phrase was, someone could take any experience and the knowledge, of any ethnic group and any nation, however in the action when someone be in a new place, then he should be based on cultural values that happen in those places. Education based on local knowledge is reflection of realization from the government regulation number 19 year 2005 about standard National education, in section 17 paragraph 1 that explain "curriculum in Senior High school and elementary school, or the other of equal rank would be develop based on the educational rank, the potential of area itself, social culture and the students itself".

Education based on local knowledge in accordance as government efforts to conserve the cultural in Indonesia. Such as education who use excellence localized in the economic aspect, culture, language, information technology and communication, ecology, and others, all of which beneficial for the development of the students. Education based the local wisdom beneficial, such as: (a) create a generation who competent and dignified; (b) reflecting the cultural values; (c) participated in develop character of the nation, (d) contribute to create the identity of the nation, and (e) participated by conserve the culture of the nation.

A method that can be used to introducing an environment in learning local beauty actually so variation. For SMP-SMA students, Bahasa Indonesia teachers, English and Bahasa Jawa teachers, can give assignments to students to make an essay about tourism city potential. For art teachers, can give the lesson about how to draw serotongan house, limasan and joglo. For Math teachers, can introduce geometris shaped to students through shape of traditonal house. Another method can be practiced is through story telling activity, with pictures, doll, instrument, traditional house miniature, or teacher's stuff.

Some of wose words that contain motivation in local language such as: (a) rame ing gawe sepi ing pamrih; (b) ing ngarsa sung tulada, ing madya mangun karsa, tutwuri handayani; (c) becik ketitik olo ketoro.

\section{CONCLUSION}

Education based on local knowledge has a big potential to create Indonesian's people with character. An expression said that, " great nation is a nation that does not leave their history". Big is just not enough, but also have to go forward. To became the big nation so the counrty should valuable and have their own character.

\section{REFERENCES}

[1] A. Margalit and J. Raz, "National Self-Determination," J. Philos., vol. 87, no. 9, pp. 439-461, 1990.

[2] C. (Ed. . Holt, Culture and Politics in Indonesia. Equinox Publishing, 2007.

[3] D. E. Ramage, Politics in Indonesia: Democracy, Islam, and the Ideology of Tolerance. Psychology Press, 1997.

[4] C. Bjork, "Decentralisation in Education, Institutional Culture and Teacher Autonomy in Indonesia," Int. Rev. Educ., vol. 50, no. 3, pp. 245-262, 2004.

[5] B. Rogoff, The Cultural Nature of Human Development. Oxford University Press, 2003.

[6] G. A. Smith, "Place-Based Education : Learning to be Where We Are," Phi Delta Kappan, vol. 83, no. 8, pp. 584-594, 2002.

[7] Y. Cheong Cheng, "Fostering Local Knowledge and Human Development in Globalization of Education," Int. J. Educ. Manag., vol. 18, no. 1, pp. 7-24, 2004.

[8] A. G. Kefalas, "Think Globally, Act Locally," Thunderbird Int. Bus. Rev., vol. 40, no. 6, pp. 547-562, 1998.

[9] J. A. Johannessen and B. Olsen, "The Future of Value Creation and Innovations: Aspects of a Theory of Value Creation and Innovation in a Global Knowledge Economy," Int. J. Inf. Manage., vol. 30, no. 6, pp. 502-511, 2010.

[10] P. A. Ertmer and A. T. Ottenbreit-Leftwich, "Teacher Technology Change: How Knowledge, Confidence, Beliefs, and Culture Intersect," J. Res. Technol. Educ., vol. 42, no. 3, pp. 255-284, 2010.

[11] L. Agung, "Character Education Integration In Social Studies Learning," Hist. Int. J. Hist. Educ. XII, no. 2, pp. 392-403, 2011.

[12] W. E. Lambert and A. Wolfgang, "Culture and Language as Factors in Learning and Education," Educ. Immigr. students, pp. 55-83, 1973. 